\title{
HOST PLANTS OF MEALYBUGS WITH THEIR DAMAGE EXTENT ON SOME SELECTED PLANTS
}

\author{
M.M.H. KHAN* \\ Department of Entomology, Patuakhali Science and Technology University, \\ Dumki, Patuakhali, Bangladesh
}

There are several species of mealybugs that can be pests of greenhouse, nursery, and landscape plants. Nearly 246 families of various plants on which 5000 species of mealybug feed have been reported all over the world (Ben-Dov 1994). According to Afzal et al. (2009) and Aheer et al. (2009), mealybugs feed on nearly 149 plant species, suck plant sap and cause leaves to distort and fall. Mealybug infestations appear on plants as tiny, soft-bodied insects surrounded by a fuzzy, white mass around the stems and leaf nodes (VanZile 2013). The papaya mealybug, Paracoccus marginatus Williams and Granara de Willink (Hemiptera: Pseudococcidae) is a small polyphagous sucking insect with pest status. It has a wide host range and great potential to damage economically important tropical fruits, vegetables and ornamental plants (Cham et al. 2011). Immature and adult stages of $P$. marginatus suck the sap of the plant and weaken it. The leaves become crinkled, yellowish and wither. The honeydew excreted by the bug and the associated black sooty mold formation impairs the photosynthetic efficiency of the affected plants. The nymphs and females of mango mealybugs suck plant sap from inflorescences, tender leaves, shoots and fruit peduncles. As a result, the infested inflorescences dry up, affects the fruit set, causing fruit drop. These bugs also exude honeydew over the mango tree leaves, on which sooty mold fungus develops, reducing the photosynthetic efficiency of the tree (Meena et al. 2014). However, so far, there are no records of host plants infested by mealybug species and their damage extent in Bangladesh. Therefore, the present study was undertaken to record the host plants infested by different mealybug species and determine the extent of damage caused by mealybug on brinjal, papaya, pigeon pea and mango.

The survey was carried out on different host plants in campus of Patuakhali Science and Technology University (PSTU), located in the southern coastal region of Bangladesh, from March to June 2014. Different plant species of fruits, vegetables and ornamental plants are grown on roadsides were selected for the study. Infested plants were examined with a magnifying glass. Samples of vegetable crops, fruits and ornamental plants were collected at weekly intervals throughout the period of study. Mealy bugs found on twigs,

*E-mail: mohasin1965@pstu.ac.bd 
leaves, branches, stems, flowers, inflorescences and roots were assorted and recorded. The mealybugs were kept in $70 \%$ alcohol. Total adults and nymphs of mealybug were counted. Some plant samples with mealybugs were preserved in a glass jar containing $70 \%$ alcohol.

Six mealybug species viz., Ferrisia virgata Ckll, Paracoccus marginatus Williams and Granara De Willink, Drosicha mangiferae, Pseudococcus longispinus, Phenacoccus solani and Maconellicoccus hirsutus were observed in different host plants. Ferrisia virgata was found on P. guajava, Solanum melongena, Annona sp. and Carica papaya. Long tailed mealybug was observed on Jatropha glandulifera and P. guajava. Mango mealybug, Rastrococcus spp. was found on Mangifera indica. Paracoccus marginatus were recorded on P. guajava, S. melongena, C. papaya, Cajanus cajan, M. indica, Corchorus olitorius and Hibiscus rosa-sinensis. Phenacoccus solani was observed in S. melongena, and P. guajava. Maconellicoccus hirsutus was recorded on 11 host plant species, namely, Codiaeum variegatum, Acalypha hispida, A. wilkesiana, Mussaenda philippica, Hibiscus rosa-sinensis (Hibiscus), Ixora grandiflora, Punica granatum, P. guajava, M. indica, Lycopersicon esculentum and H. rosa-sinensis (Table 1). Mealybugs were found to cause serious damage to succulent plants (Fig. 1a-m).

The number of $P$. solani on various plant parts of brinjal is presented in Fig. 2. It has been illustrated that the highest number of mealybug was found on a mature leaf (141.4) while the highest percent area covered by mealybug was found on a young leaf (74\%) (Fig. 3). Fig. 4 revealed that the highest number of $1^{\text {st }}$ instar per leaf followed by $3^{\text {rd }}$ and $2^{\text {nd }}$ instar nymphs was recorded in brinjal. The ventral surface of foliage and fruit, along with the calyx of brinjal, was damaged by $P$. solani shown in Fig. 1d. The variation in the number of mealybug on different aged leaves might be due to the nutritional variation of brinjal leaves. It was reported by Evans (1984) that monophagous and oligophagous herbivores often show strong preferences for the more nutritious, younger leaf tissues that are high in toxins, where polyphagous herbivores demonstrate a strong preference for the less nutritious, mature leaf tissues. As mealybug is a polyphagous pest, it might have a preference for mature leaves to young leaves.

Fig. 5 illustrated that the number of mealybug per colony was maximum (67) on the leaf stalk. Likewise, the percentage of leaf stalk infestation per plant was $86.42 \%$, while the area of a leaf covered by mealybug colonies was $41.75 \%$. On highly infested plants, papaya mealybug looked like small pieces of cotton attached to the plant. On heavily infested plants, the mealybug colonies formed cotton-like masses on the aerial parts (Fig. 1b). 
Table 1. Host plants of six mealybug species at PSTU campus.

\begin{tabular}{|c|c|c|c|}
\hline $\begin{array}{l}\text { Common name } \\
\text { of mealybug }\end{array}$ & $\begin{array}{l}\text { Scientific name of } \\
\text { mealybug }\end{array}$ & $\begin{array}{l}\text { Common name } \\
\text { of host plant }\end{array}$ & Scientific name of host plant \\
\hline $\begin{array}{l}\text { Guava mealybug } \\
\text { (Fig. 1a) }\end{array}$ & Ferrisia virgata Ckll & $\begin{array}{l}\text { Guava } \\
\text { Custard apple } \\
\text { Sharifa } \\
\text { Brinjal } \\
\text { Papaya }\end{array}$ & $\begin{array}{l}\text { Psidium guajava } \\
\text { Annona sp. } \\
\text { Annona squamosa } \\
\text { Solanum melongena } \\
\text { Carica papaya } \mathrm{L} .\end{array}$ \\
\hline $\begin{array}{l}\text { Long tailed mealybug } \\
\text { (Fig. 1a) }\end{array}$ & Pseudococcus longispinus & $\begin{array}{l}\text { Jatropha } \\
\text { Guava }\end{array}$ & $\begin{array}{l}\text { Jatropha glandulifera } \\
\text { Psidium guajava }\end{array}$ \\
\hline $\begin{array}{l}\text { Papaya mealybug } \\
\text { (Fig. } 1 \mathrm{~b} \& \mathrm{e} \text { ) }\end{array}$ & $\begin{array}{l}\text { Paracoccus marginatus } \\
\text { Williams and Granara } \\
\text { De Willink }\end{array}$ & $\begin{array}{l}\text { Papaya } \\
\text { Guava } \\
\text { Brinjal } \\
\text { Pigeon pea } \\
\text { Mango } \\
\text { Jute } \\
\text { China rose }\end{array}$ & $\begin{array}{l}\text { Carica papaya } \mathrm{L} . \\
\text { Psidium guajava } \\
\text { Solanum melongena } \mathrm{L} . \\
\text { Cajanus cajan (Linn.) } \\
\text { Mangifera indica } \mathrm{L} . \\
\text { Corchorus olitorius } \mathrm{L} \text {. } \\
\quad \text { Hibiscus rosa-sinensis } \mathrm{L}\end{array}$ \\
\hline $\begin{array}{l}\text { Mango mealybug } \\
\text { (Fig. 1c) }\end{array}$ & Drosicha mangiferae & Mango & Mangifera indica $\mathrm{L}$. \\
\hline $\begin{array}{l}\text { Brinjal mealybug } \\
\text { (Fig. 1d) }\end{array}$ & Phenacoccus solani & $\begin{array}{l}\text { Brinjal } \\
\text { Guava }\end{array}$ & $\begin{array}{l}\text { Solanum melongena } \\
\text { Psidium guajava }\end{array}$ \\
\hline $\begin{array}{l}\text { Pink hibiscus } \\
\text { mealybug } \\
\text { (Fig. 1f-m) }\end{array}$ & Maconellicoccus hirsutus & $\begin{array}{l}\text { Maite patabahar } \\
\text { Lal hatisur } \\
\text { Khat Patabahar/ } \\
\text { Copper leaf } \\
\text { White double } \\
\text { mussaenda } \\
\text { Rangan } \\
\text { China rose } \\
\text { Pomegranate } \\
\text { Guava } \\
\text { Mango } \\
\text { Tomato } \\
\text { Daffodil } \\
\text { (Hallod jaba) }\end{array}$ & $\begin{array}{l}\text { Codiaeum variegatum } \\
\text { Acalypha hispida } \\
\text { Acalypha wilkesiana 'Dwarf' } \\
\text { Mussaenda philippica } \\
\text { 'Aurorae' } \\
\text { Ixora grandiflora } \\
\text { Hibiscus rosa-sinensis L } \\
\text { Punica granatum L. } \\
\text { Psidium guajava } \\
\text { Mangifera indica L. } \\
\text { Lycopersicon esculentum Mill. } \\
\text { Hibiscus rosa-sinensis L }\end{array}$ \\
\hline
\end{tabular}



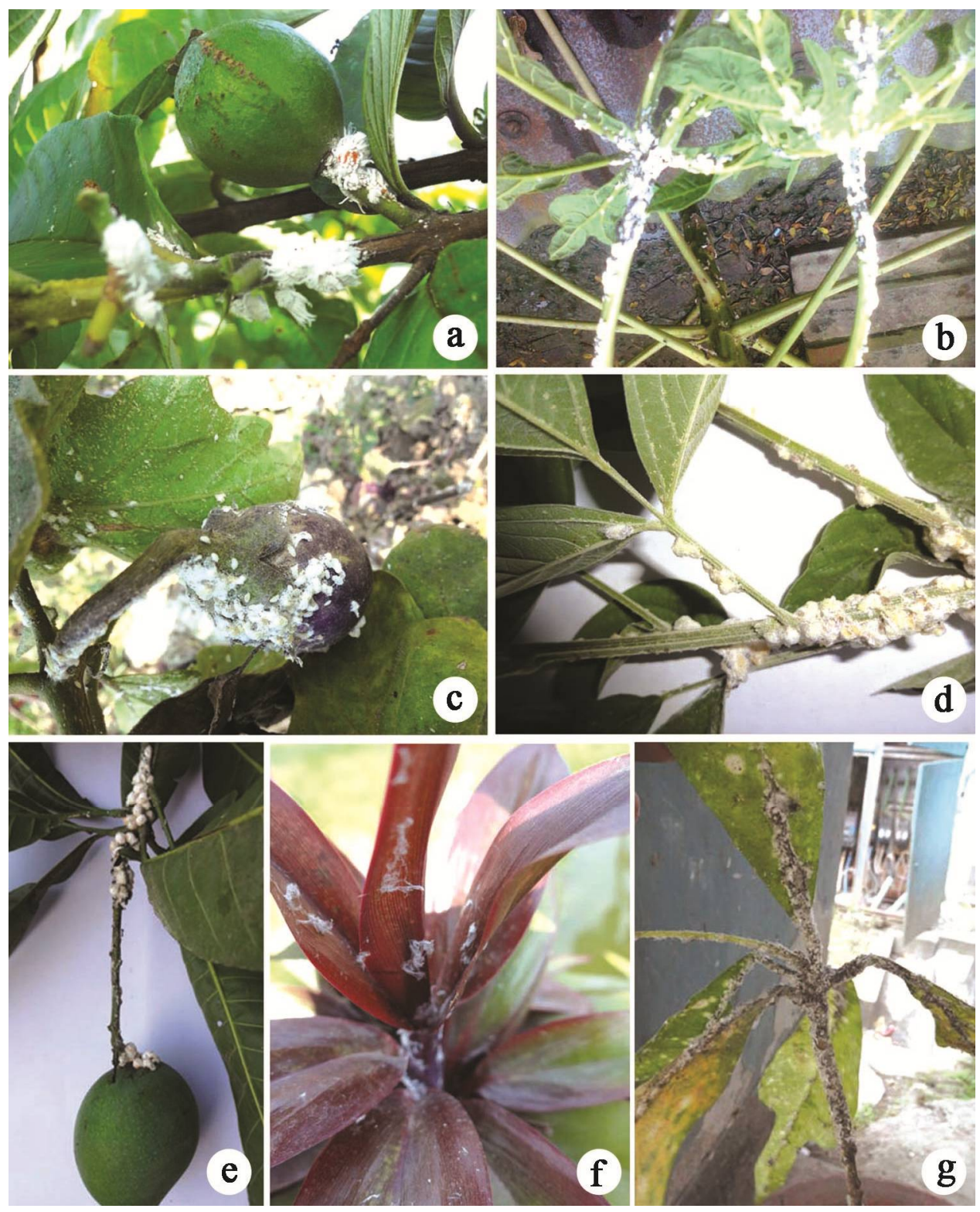

Fig.1(a-g): (a). Psidium guajava. (b). Carica papaya, (c). Solanum melongena, (d). Cajanus cajan, (e), Mangifera indica, (f). Cordyline terminalis, (g). Codiaeum variegatum Elite. 

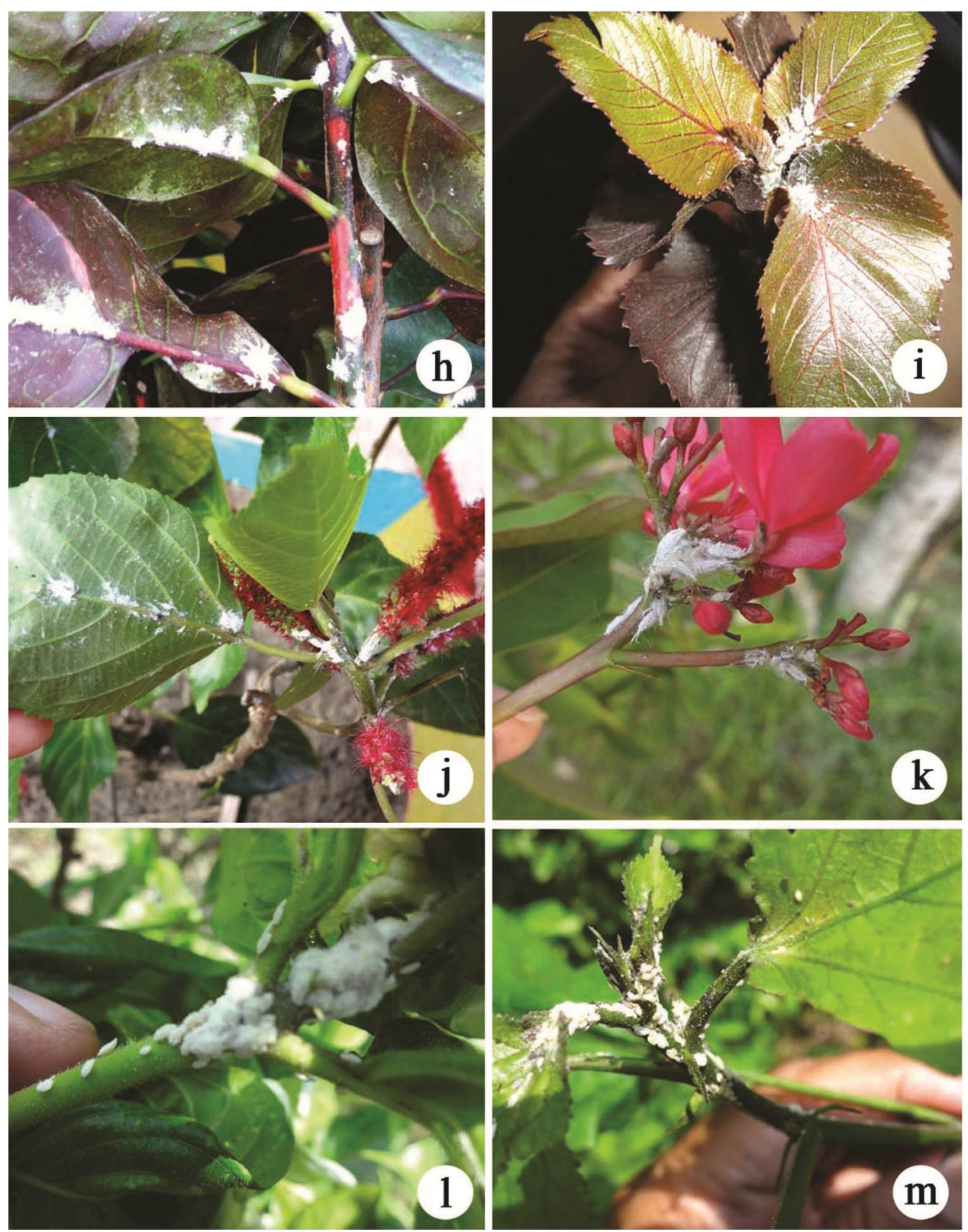

Fig. 1(h-m): (h). Codiaeum variegatum Elite, (i). Acalypha wilkesiana, (j). Acalypha hispida, (k). Jatropha glandulifera, (l). Mussaenda philippica, (m). Hibiscus rosa-sinensis. 


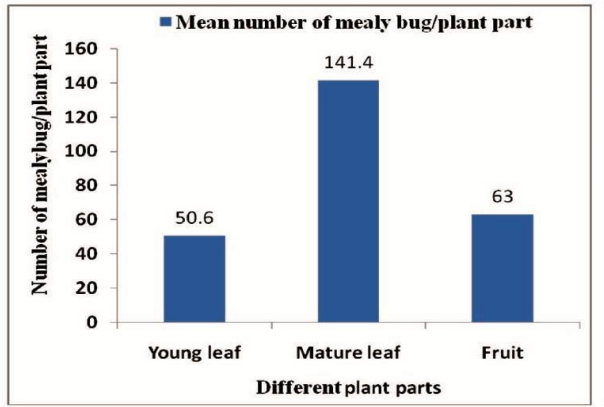

Fig. 2. Number of Phenacoccus solani on leaf and fruit of brinjal.

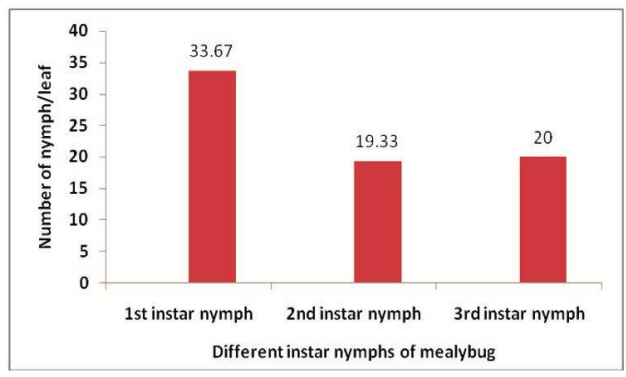

Fig. 4. Different instar nymphs of Phenacoccus solani per leaf of brinjal.

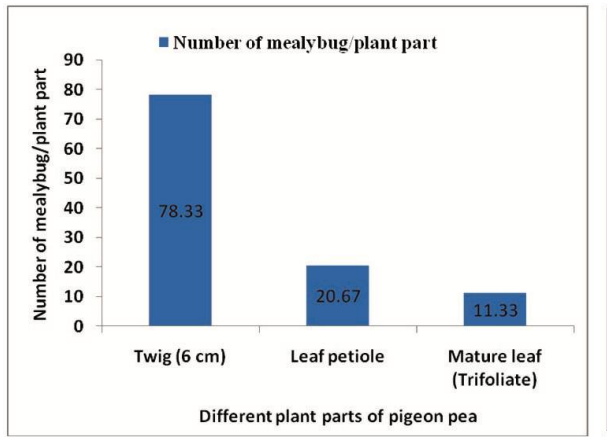

Fig. 6. Number of Paracoccus marginatus on plant parts of Pigeon pea.

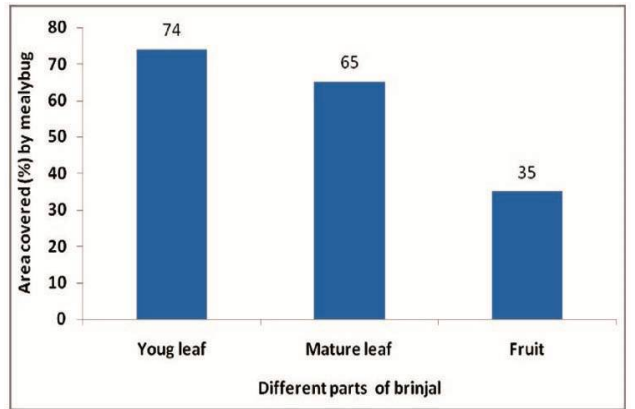

Fig. 3. Percentage of the area covered by Phenacoccus solani on leaf and fruit of brinjal.

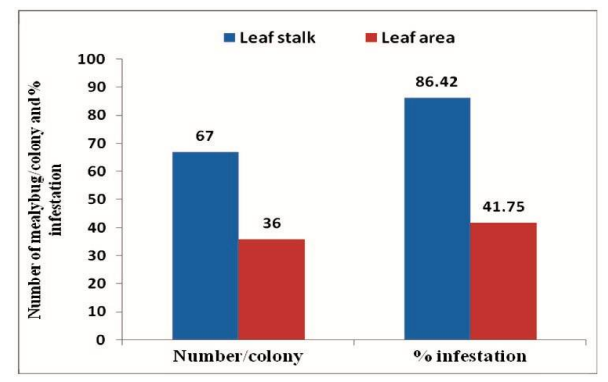

Fig. 5. Percentage of leaf stalk infestation per plant and leaf area covered by Paracoccus marginatus.

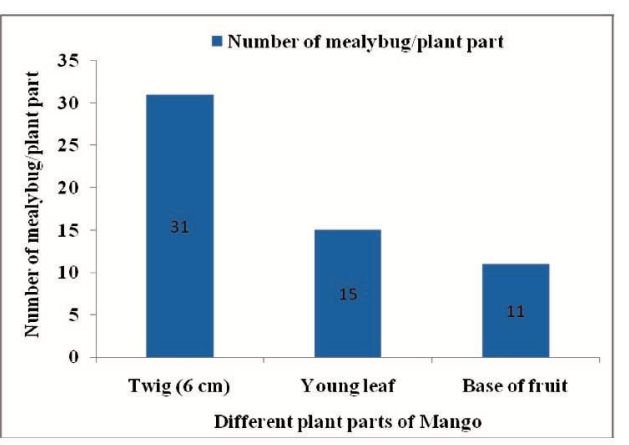

Fig. 7. Number of Drosicha mangiferae plant parts of Mango. 
These damage symptoms resembled those caused by papaya mealybug described by Walker et al. (2003) and Hue et al. (2007).

Fig. 6 revealed that the highest number of mealybug was found on $6 \mathrm{~cm}$ twig (78.33), followed by leaf petiole (20.67), while the lowest was in trifoliate mature leaf (11.33).

Fig. 7 revealed that the highest number of Drosicha mangiferae was found on $6 \mathrm{~cm}$ twig (31), followed by young leaf (15), while the lowest number was in the base of fruit (11).

In this study, six mealybug species were enlisted, which caused damage to several host plant species. The author is grateful to the authority of Patuakhali Science and Technology University for financial assistance to carry out the research work.

\section{References}

Afzal, M., S.U. Rahman and M.T. Siddiqui. 2009. Appearance and management of a new devastating pest of cotton, Phenacoccus solenopsis Tinsley, in Pakistan. Belt-wide Cotton Conference, San Antonio, Texas, pp. 5-8.

G.M. Aheer, Z. Shah and M. Saeed. 2009. Seasonal history and biology of cotton mealy bug, Phenacoccus solenopsis Tinsley. J. Agric. Res. 47(4): 423-431.

Ben-Dov, Y. 1994. A systematic catalogue of the mealybugs of the world, Intercept Limited, UK, p. 686.

Cham, D., H. Davis, D. Obeng-Ofori and E. Owusu. 2011. Host range of the newly invasion mealybug species Paracoccus marginatus Williams and Granara De Willink (Hemiptera: Pseudococcidae) in two ecological zones of Ghana. Res. Zool. 1(1): 1-7.

H.E. Evans. 1984. Insect Biology: A textbook of Entomology. Addison-Wesley Publishing Company, Massachusetts-California-London-Amsterdam-Ontario-Sydney. p. 436.

Heu, R.A., M.T. Fukada and P. Conant. 2007. Papaya mealybug, Paracoccus marginatus Williams and Granara de Willink (Hemiptera: Pseudococ-cidae). State of Hawaii New Pest Advisory. Department of Agriculture No. 04-03 March 2007.

Meena, B.M., A. Chattopadhyay, S.C. Meena and S.S. Rathore. 2014. Package and Practices for Integrated Pest Management of Mango (Mangifera indica). Popular Kheti. 2(3): 100-108.

VanZile, J. 2013. Mealybugs- How to Control Mealy bugs.

Walker A., M. Hoy and D.E. Meyerdirk. 2003 Papaya Mealybug. Univ. Florida Featured Creatures.http://creatures.ifas.ufl.edu/fruit/mealybugs/papaya_mealybug.htm (Accessed on $29 \mathrm{Sept}$ 2008) 